\title{
Wymiar sprawiedliwości Warszawskiego Okręgu Wojskowego armii rosyjskiej na przełomie XIX i XX wieku
}

\author{
Justice Warsaw Military District of the Russian army at the turn \\ of the 19th and 20th century
}

\section{STRESZCZENIE:}

W omawianym okresie Warszawski Okręg Wojskowy obejmował tereny większości Królestwa Polskiego oraz niektórych powiatów guberni grodzieńskiej i wołyńskiej. Struktura organizacyjna okręgu była rozbudowana i analogiczna do struktury rosyjskiego Ministerstwa Wojny. Na czele okręgu stał generał-gubernator, będący jednocześnie dowódcą wojsk okręgu. Podlegały mu wojska regularne i nieregularne oraz wszelkie instytucje wojskowe znajdujące się na tym terenie, w tym wydział sądowy wraz z sądem okręgowym i sądami pułkowymi. W ich skład wchodzili oficerowie mający odpowiedni poziom wykształcenia prawniczego i praktykę zawodową. Obowiązujące przepisy regulowały zakres oraz tryb rozpatrywanych spraw sądowych. Stan etatowy zarządu sądowego Warszawskiego Okręgu Wojskowego wynosił około 90 osób, jednak stopniowo ulegał zwiększeniu. W jego składzie znajdowali się: prezes sądu, ośmiu sędziów, trzech (potem pięciu) śledczych, dziesięciu prokuratorów oraz personel pomocniczy. Skład personalny był przeważnie rosyjski, lecz spotykało się także przedstawicieli innych narodowości, w tym Polaków (Leon Iwanowski).

Słowa kluczowe: Rosja, armia, Warszawa, okręg wojskowy, sądownictwo

Na przełomie XIX i XX wieku Cesarstwo Rosyjskie było jednym z najrozleglejszych państw świata. Kluczowe znaczenie dla Rosji miały okręi zachodnie, w tym utworzony jako jeden z pierwszych (jeszcze w 1862 r.) Warszawski Okręg Wojskowy (WOW). Początkowo obejmował on tereny całego Królestwa Polskiego. W 1875 r. oddzielono od niego gubernię suwalska, którą przyłączono do Wileńskiego Okręgu Wojskowego. W 1894 r. 
ponownie zmieniono granice WOW, do którego przyłączono niektóre powiaty guberni grodzieńskiej i wołyńskiej. W omawianym okresie w jego skład wchodziły gubernie: kaliska, piotrkowska, kielecka, radomska, lubelska, siedlecka, warszawska, płocka, łomżyńska oraz niektóre powiaty guberni grodzieńskiej (sokołowski, białostocki, wołkowyski, bielski, brzeski, prużański i kobryński) i wołyńskiej (włodzimierski i kowelski). Taki stan rzeczy obowiązywał do 1912 r., tj. do likwidacji guberni siedleckiej. Okręg w tym kształcie funkcjonował do wybuchu I wojny światowej ${ }^{1}$.

Struktura organizacyjna WOW była rozbudowana i analogiczna do struktury rosyjskiego Ministerstwa Wojny. Na czele okręgu stał generałgubernator, będący jednocześnie dowódcą wojsk okręgu. Podlegały mu wojska regularne i nieregularne oraz wszelkie instytucje wojskowe znajdujące się na podległym terenie.

Przy dowódcy okręgu obradowała Okręgowa Rada Wojskowa, która miała rozpatrywać sprawy gospodarcze okręgu, głównie finansowe. Tworzyli ją: przewodniczący - dowódca okręgu, oraz członkowie - pomocnik dowódcy okręgu, szef sztabu okręgu, intendent okręgu, szef artylerii okręgu, szef inżynierów okręgu, okręgowy inspektor medyczny, inspektor szpitali i przedstawiciel Ministerstwa Wojny. Niekiedy do składu rady wyznaczano także dowódców korpusów i wybranych dowódców dywizji (głównie gwardii) ${ }^{2}$.

Generał-gubernatorowi podlegały sztab okręgu oraz specjalistyczne zarządy: artylerii, inżynierii, intendentury i medyczny oraz wojska regularne i nieregularne stacjonujące w $\mathrm{WOW}^{3}$.

Sztab okręgu miał kierować procesem dowodzenia wojskami, zbierać i przetwarzać informacje potrzebne do mobilizacji oraz zbierać informacje o stanach osobowych jednostek i instytucji wojskowych w okręgu. Szefa sztabu wybierał minister wojny $\mathrm{w}$ porozumieniu $\mathrm{z}$ dowódcą okręgu. Sztab składał się z trzech zarządów:

- zarządu generała-kwatermistrza, który składał się z trzech oddziałów: liniowego (skład i dyslokacja oddziałów wojskowych, udział w manewrach i drogi marszu), mobilizacyjnego i ogólnego ds. służby Sztabu

1 Archiwum Państwowe w Lublinie (APL), Rząd Gubernialny Lubelski (RGL) (1867-1918), sygn. WP II 1894:46, cz. 1, Приказ войскам Варшавского Военного Округа (ПВВВО), 1894, nr 114; Свод Военных Посатновлений 1869 года (СВП 1869 года), ks. II, С.Петербург 1893, art. 1; Военная Энициклопедия, red. К. Величко, t. 5, С.-Петербург 1911, s. 247.

${ }^{2}$ СВП 1869 zoда, ks. II, art. 57-78; zob. APL, RGL (1867-1918), sygn. WP II 1914:24, ПВВВО, 1914, nr 4; M. Kulik, Warszawski Okręg Wojskowy Rosyjskiej Cesarskiej Armii (18941914), „Przegląd Historyczno-Wojskowy” 2008, nr 4, s. 5-24.

${ }^{3}$ СВП 1869 zода, ks. II, art. 3-6; Die Russische Armee, Wien 1901, s. 156-159. 
Generalnego (statystyczny, zbieranie informacji statystycznych i topograficznych o terenie okręgu i państw sąsiednich);

- zarządu dyżurnego generała, który składał się z oddziałów: inspektorskiego, gospodarczego i szpitalnego;

- zarządu komunikacji wojskowej (przewóz oddziałów i sprzętu wojskowego, nadzór na oddziałami etapowymi).

Oprócz wymienionych zarządów w skład sztabu wchodziły również kancelaria sztabu, wydział sądowy i archiwum sztabu okręgu' ${ }^{4}$.

Zasady działania wojskowego resortu sprawiedliwości określały przepisy zawarte w XXIV tomie Zbioru Przepisów Wojskowych z 1869 r.

Okręgowy sąd wojskowy wszedł w struktury sztabu pod koniec lat 60. XIX wieku, co było związane $\mathrm{z}$ wprowadzanymi w życie kolejnymi reformami wojskowymi, w tym także dotyczącymi przepisów prawnych obowiązujących $\mathrm{w}$ armii. $\mathrm{W}$ miejsce dotychczas działających audytoriatów i komisji wprowadzono nowe struktury - Główny Sąd Wojskowy, sądy okręgowe i sądy pułkowe ${ }^{5}$.

Wszystkie sądy wojskowe były sądami kolegialnymi. Śledztwa prowadzili śledczy wojskowi, natomiast nadzór prokuratorski sprawował prokurator wojskowy i jego pomocnicy ${ }^{6}$.

Sądem wyższej instancji był sąd okręgowy działający przy sztabie okręgu wojskowego. Dla WOW znajdował się on w Warszawie. W jego skład wchodzili członkowie stali i okresowi. Do członków stałych zaliczano prezesa sądu (w stopniu oficera starszego ${ }^{7}$ ) i etatowych sędziów wojskowych (w stopniu oficera starszego lub młodszego, mogli to być również urzędnicy wojskowi). Na swoje stanowiska byli wyznaczani rozkazem ministra wojny. Okresowymi członkami okręgowych sądów wojskowych byli oficerowie wyznaczeni z jednostek wojskowych stacjonujących w danym okręgu - dwóch oficerów starszych (dowodzący co najmniej dwa lata batalionem) i dwóch oficerów młodszych (dowodzący co najmniej cztery lata kompanią lub szwadronem). O wyborze okresowych członków sądów zawiadamiano w specjalnym rozkazie dowódcy okręgu wojskowego. Osoby te były wyznaczane z jednostek leżących najbliżej miejsca posiedzeń sądu. Na wypadek choroby jednego z członków

${ }^{4}$ СВП 1869 года, ks. II, art. 79-102.

${ }^{5}$ А. Безугольный, Н. Ковалевский, В. Ковалев, История военно-окружной системь в России 1862-1918, Москва 2012, s. 119.

${ }^{6}$ СВП 1869 года, ks. XXIV, art. 5-6.

${ }^{7}$ Rosyjski korpus oficerski w tym czasie dzielił się na trzy grupy: oficerów młodszych (ober-oficerów), do których zaliczano podporucznika, porucznika, sztabs-kapitana (sztabs-rotmistrz) i kapitana (rotmistrz); oficerów starszych (sztab-oficerów), do których zaliczano podpułkowników i pułkowników; generałów, do których zaliczano generałów majorów, generałów lejtnantów i generałów broni. 
sądu zawsze była wyznaczana osoba rezerwowa, która mogłaby zająć miejsce nieobecnego. W przypadku, gdy sądzono oficera starszego, wśród okresowych członków sądu byli sami oficerowie starsi. Jeżeli podsądnym była osoba zajmująca wysokie stanowisko służbowe, wśród okresowych członków sądu były osoby zajmujące co najmniej równorzędne mu stanowisko ${ }^{8}$.

Sądy okręgowe mogły prowadzić sprawy dotyczące generałów i oficerów oraz urzędników wojskowych, żołnierzy niższych rangą rozpatrywały apelacje sądów pułkowych oraz doniesienia składane przez wojskowych prokuratorów i śledczych ${ }^{9}$.

Sądy pułkowe znajdowały się przy każdej samodzielnej jednostce wojskowej. W ich skład wchodziły trzy osoby: przewodniczący i dwóch członków. Przewodniczący sądu pułkowego był wyznaczany spośród oficerów w randze podpułkownik-pułkownik, zajmujących stanowisko służbowe dowódcy batalionu, dywizjonu lub młodszego sztab-oficera w pułku. Członków wyznaczano spośród oficerów zajmujących stanowisko dowódcy kompanii lub szwadronu. Skład sądu wyznaczał dowódca jednostki, przewodniczącego na okres roku, a członków na pół roku ${ }^{10}$.

W skład sądów wojskowych mogli wejść tylko oficerowie, którzy zaliczyli kurs wojskowych nauk prawnych i mieli kilkuletni staż na stanowisku dowódczym (kompanii lub batalionu) ${ }^{11}$. Żaden członek sądu nie mógł być karany ani nie mogło być prowadzone w jego sprawie śledztwo.

Do rozpatrywania spraw sądowych w miastach oddalonych od siedziby sądu okręgowego organizowano specjalne okresowe sądy wojskowe. Posiedzenia tych sądów mogły się odbyć tylko dwa razy w roku w tym samym garnizonie. Wyjątek czyniono w razie zajścia wypadków nadzwyczajnych lub rażącego naruszenia dyscypliny. Sąd okresowy składał się ze stałego członka - pełniącego obowiązki prezesa oraz członków okresowych. Stały członek był etatowym pracownikiem wojskowego sądu okręgowego, natomiast członków okresowych wyznaczano spośród oficerów konkretnych jednostek ${ }^{12}$.

Przy każdym sądzie znajdowała się kancelaria zajmująca się bieżącą korespondencją i dokumentacją prowadzonych spraw. Obsługiwali ją sekretarze i ich pomocnicy ${ }^{13}$.

${ }^{8}$ СВП 1869 года, ks. XXIV, art. 24-44; А. Безугольный, Н. Ковалевский, В. Ковалев, op. cit., s. 120.

${ }^{9}$ СВП 1869 года, ks. XXIV, art. 260-261.

${ }^{10}$ СВП 1869 года, ks. XXIV, art. 9-23.

${ }^{11}$ Ibidem, art. 81-89.

${ }^{12}$ Ibidem, art. 45-52.

${ }^{13} \mathrm{Ibidem}$, art. 75-80. 
Posiedzenia sądów odbywały się w specjalnie przygotowanych do tego pomieszczeniach, przy drzwiach zamkniętych ${ }^{14}$.

Raz w roku dowódca jednostki wojskowej, w której obradował sąd pułkowy, składał przełożonym sprawozdanie o działalności podległego sobie sądu. Podobnie czyniono także w przypadku sądów okręgowych i okresowych. Wszystkie te sprawozdania służyły potem do sporządzenia raportu z działalności Ministerstwa Wojny za dany rok kalendarzowy ${ }^{15}$.

Pracownikami wojskowego resortu sprawiedliwości mogli być tylko oficerowie, którzy byli poddanymi rosyjskimi i mieli wykształcenie wojskowo-prawnicze.

Kandydat na stanowiska:

- prezesa sądu okręgowego - musiał wcześniej piastować urząd sędziego wojskowego lub prokuratora wojskowego,

- sędziego wojskowego - musiał wcześniej być śledczym wojskowym lub pomocnikiem prokuratora wojskowego ${ }^{16}$.

Stan etatowy zarządu sądowego WOW wynosił 88 osób. Z czasem stan etatowy ulegał zwiększeniu, jednak nie był stały. W 1912 r. wynosił 97, a w 1915 r. - 94 osoby. W jego skład wchodzili:

Prezes okręgowego sądu wojskowego - 1 - z dochodem 5400 rubli rocznie.

Sędziowie okręgowego sądu wojskowego - 6 (9 w 1915 r.) - każdy $\mathrm{z}$ dochodem 4125 rubli rocznie.

Śledczy wojskowi - 7 (10 w 1915 r.) - każdy z dochodem 2500 rubli rocznie.

Sekretarz sądu - 1 - z dochodem 1875 rubli rocznie.

Pomocnicy sekretarza - 6 (11 w 1915 r.) - każdy z dochodem 1125 rubli rocznie.

Kandydaci na stanowiska w wojskowym resorcie sprawiedliwości - 4 - każdy z dochodem 1200 rubli rocznie.

Tłumacze - 2 - każdy z dochodem 937,50 rubli rocznie.

Pisarze - 14 (17 w 1915 r.) - 5 wyższej klasy - każdy z dochodem 60 rubli rocznie, 5 średniej klasy - każdy z dochodem 36 rubli rocznie, 4 niższej klasy - każdy z dochodem 24 rubli rocznie.

Nadzór prokuratorski:

Prokurator wojskowy $-1-\mathrm{z}$ dochodem 5250 rubli rocznie.

Zastępcy (pomocnicy) prokuratora wojskowego - 11 (12 w 1915 r.) każdy z dochodem 2500 rubli rocznie.

\footnotetext{
${ }^{14}$ Ibidem, art. 90-96.

${ }^{15}$ Ibidem, art. 122-130.

${ }^{16}$ Ibidem, art. 148-152.
} 
Sekretarz prokuratora wojskowego - 1 - z dochodem 1380 rubli rocznie.

Kandydaci na stanowiska w wojskowym wymiarze sprawiedliwości $-2-\mathrm{z}$ dochodem 1200 rubli rocznie.

Tłumacz $-1-z$ dochodem 750 rubli rocznie.

Pisarze - 20 (21 w 1915 r.) - wyższej klasy - każdy z dochodem 60 rubli rocznie, 6 średniej klasy - każdy z dochodem 36 rubli rocznie, 7 niższej klasy - każdy z dochodem 24 rubli rocznie ${ }^{17}$.

Na czele zarządu stał prezes sądu w stopniu generała lejtnanta. W omawianym okresie stanowisko to zajmowali: Fiodor Jefimowicz Strielnikow (1897-1906), Nikołaj Fiedotowicz Doroszewskij (1907-1909), Siergiej Fiodorowicz Krechowiecki-Juszczenko (1910-1912) i Wasilij Aleksiejewicz Arbuzow (1903-1914) ${ }^{18}$.

Skład sędziowski liczył 8 członków, początkowo były to osoby w stopniu pułkownika, a później generała majora. Każdy sędzia, który pierwszy raz uczestniczył $\mathrm{w}$ pracach sądu, składał przysięgę przed duchownym tego samego, co on sam wyznania ${ }^{19}$. Wśród sędziów byli: Michaił Jemielianowicz Afanasjew (1907), Aleksander Aleksandrowicz Birszert (1903-1905), Iwan Michajłowicz Cholawko (1900), Marceli Stanisławowicz Chonskij (1907-1914), Michaił Ardalionowicz Djakow (19091914), Paweł Aleksandrowicz Dorogoj (1897-1897), Nikołaj Fiodorowicz Doroszewski (1897-1898), Aleksander Michajłowicz Gorskij (1900-1906), Mitrofan Iwanowicz Jakubowskij (1897-1906), Siergiej Giergijewicz Jawlenskij (1913-1914), Anatolij Francewicz Kaminskij (1908-1914), Jewgienij Nikołajewicz Koziełkin (1907-1914), Siergiej Iwanowicz Maszrub-Szowerdow (1897), Aleksander Pawłowicz Miłkow (1907), Siergiej Piotrowicz Minin (1904-1906), Wasilij Aleksiejewicz Mower (1897-1898), Aleksander Aleksandrowicz Musznikow (1898-1900), Władimir Nikandrowicz Niszczenkow (1904-1906), Wasilij Konstantinowicz Pienkin (1907), Lew Antonowicz Płanson (1908-1914), Władimir Andriejewicz Rossowskij (1897-

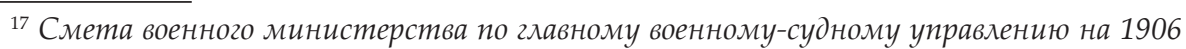
год, [b.m.w.] 1906, s. 20; Смета военного министерства по главному военному-судному управлению на 1907 год, [b.m.w.] 1907, s. 24-25; Смета военного министерства по главному военному-судному управлению на 1915 год, [b.m.w.] 1915, s. 22-23.

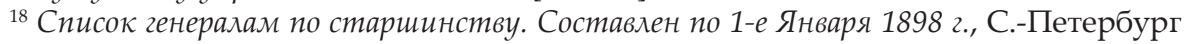
1898; Список генералам по стариинству. Составлен по 1-е Июля 1900 2., С.-Петербург 1900; Список генералам по стариинстьу. Составлен по 1-е Сентября 1905 2., С.-Петербург 1905; Список генералам по стариинству. Составлен по 1-е Января 1910 2., С.-Петербург 1910; Список генералам по стариинстьу. Составлен по 15-е Апреля 1914 2., С.-Петербург 1914, С. В. Волков, Генералитет Российской Империи. Энииклопедический словарь генералов и адмиралов от Петра I до Николая II, t. I-II, Москва 2010.

${ }^{19}$ СВП 1869 года, ks. XXIV, art. 158. 
1905), Georgij Iwanowicz Rudenko (1907-1914), Aleksander Fiodorowicz Sieleckij (1907-1908), Aleksiej Wasijewicz Stanisławskij (1897), Walerian Wasiljewicz Szapko (1903-1909), Piotr Aleksandrowicz Szwejkowskij (1906), Nikołaj Fiodorowicz Tarasienkow (1910-1914), Wasilij Nikołajewicz Uwerskij (1908-1914), Wiktor Wiktorowicz Wysotskij (1897-1906) i Michaił Nikołaj Zagoskin (1903) ${ }^{20}$.

Stanowisko śledczego wojskowego zajmował oficer w stopniu pułkownika. Początkowo funkcjonowały trzy takie etaty. Ich liczbę wkrótce zwiększono do pięciu. Stanowisko śledczych wojskowych zajmowali: Siergiej Arkadjewicz Borysoglebskij (1908-1914), Marceli Stanisławowicz Chonskij (1896-1901), Władimir Dmitrjewicz Ditiatjew (1897), Aleksander Michajłowicz Dobrianskij (1907-1914), Jakow Jewgienjewicz Duble (1895-1896), Gustaw Adolfowicz Firenkranc (1911-1914), Diodor Piotrowicz Granowskij (1907-1908), Piotr Pawłowicz Gorodeckij (1908-1914), Leon Konstantinowicz Iwanowskij (1916-1912), Siergiej Giergijewicz Jawlenskij (1911-1912), Aleksander Pawłowicz Miłkow (1896-1901), Friedrich Adolfowicz Perzeke (1899-1901), Grigorij Grigorjewicz Peretc (1910), Lew Antonowicz Płanson (1898-1902), Iwan Ardalionowicz Płanson (1908), Nikołaj Aleksandrowicz Potapow (1907-909), Georgij Iwanowicz Rudenko (1897-1900), Anatolij Iwanowicz Smirnow (1910-1913), Nikołaj Fiodorowicz Tarasienkow (1907-1908) i Jewgienij Konstantinowicz Tomilin $(1908-1913)^{21}$.

Stanowisko prokuratora wojskowego zajmował oficer w stopniu generała majora. W omawianym okresie stanowisko to zajmowali: Paweł Iwanowicz Bogdanow (1898-1903), Nikołaj Władimirowicz Kaznaczajew (1908-1914), Piotr Piotrowicz Muchin (1904-1906), Władimir Nikanorowicz Niszczenkow (1907), Aleksander Timofiejewicz Semplikiewicz (1897). Podlegało mu siedmiu, a z czasem dziewięciu pomocników. Byli to oficerowie w stopniach kapitana lub podpułkownika. Stanowisko to w omawianym okresie zajmowali: Anatolij Władimirowicz Abdułow (19091912), Paweł Nikołajewicz Aleksandrow (1898), Aleksander Aleksandrowicz Andrianow (1897-1898), Aleksander Piotrowicz Andriejew (1900), Aleksander Nikołajewicz Bielawskij (1913), Konstantin Iwanowicz Bołdeskul (1912), Siergiej Arkadiewicz Borysoglebskij, Andriej Władimiro-

${ }^{20}$ Список генералам...1-е Января 1898 г.; Список генералам...1-е Июля 1900 г.; Список генералам...1-е Сентября 1905 г.; Список генералам...1-е Января 1910 г.; Список генералам... 15-е Апреля 1914 г.; С. В. Волков, ор.cit.

${ }^{21}$ Список полковникам по стариинству. Составлен по 1-е Мая 1901 г., С.-Петербург 1901; Список полковникал по старшинству. Составлен по 1-е Января 1902 г., С.-Петербург 1902; Список полковникам по старшинству. Составлен по 1-е Марта 1912 г., С.-Петербург 1912; С. В. Волков, op.cit. 
wicz Chaskin (1897), Konstantin Aleksandrowicz Czywadze (1898-1900), Michaił Ardalionowicz Djakow (1906-1908), Aleksander Michajłowicz Dobrowolskij (1897-1900), ks. Siergiej Aleksandrowicz Druckoj (1903), Gustaw Juliewicz Firenkranc (1908), Nikołaj Pawłowicz Girs (1908-1913), Diodor Piotrowicz Granowskij (1896-1901), Piotr Pawłowicz Gorodeckij (1907-1909), Władimir Jewgrafowicz Ignatowicz (1898-1900), Leon Konstanty Iwanowskij (1906-1907), Siergiej Georgijewicz Jawlenskij (19031909), Aleksander Fiodorowicz Jerancow, Paweł Jewgieniewicz Kamienskij (1905-1906), Wiaczesław Wiaczesławowicz Kann (1912), Aleksander Robertowicz Kretcer (1908-1913), Iwan Piotrowicz Kuleszow (1908-1913), Maksym Ksenofontowicz Linkin (1900-1907), Georgij Ipolitowicz Lisowskij (1912-1913), Władimir Ilicz Ładyżenskij (1911), Władimir Iwanowicz Łazariew (1906-1908), Władimir Władimirowicz Nikitin, Iwan Ardalionowicz Panow, Friedrich Adolfowicz Perzeke (1898), Lew Antonowicz Płanson (1893-1898), Siergiej Aleksandrowicz Polakow (1897), Nikołaj Aleksandrowicz Potapow (1900-1906), Aleksandr Siemionowicz Riezanow (1912-1913), Nikołaj Nikołajewicz Sawiełow (1908-1912), Lew Piotrowicz Siemienow (1911-1913), Anatolij Iwanowicz Smirnow (1913-1914), Borys Władimirowicz Szawrow (1904-1906), Lew Iwanowicz Szebeko (1897), Konstantin Nikołajewicz Szrejterfeld (1904-1908), Nikołaj Fiodorowicz Tarasienkow (1900), Aleksiej Aleksandrowicz Wołodkowskij (1903-1906), Nikołaj Nikołajewicz Zabiełło (1903-1906), Adam Aleksandrowicz Zaliwskij (1897-1898) i Aleksander Nikołajewicz Zielenskij (1905-1914)22.

Skład wojskowego wymiaru sprawiedliwości w Warszawskim OW pod względem narodowościowym był w dużej mierze rosyjski. Spotykało się pojedynczych przedstawicieli innych narodowości, Niemców (głównie tzw. Bałtów) a także Polaków. Osób polskiego pochodzenia mogło być kilka, np. Marceli Chonskij, Leon Iwanowskij czy Anatol Kaminskij. Wskazują na to brzmienie nazwisk, imion i imion ojców, jednak tylko w przypadku Leona Iwanowskiego można mieć pewność, że był Polakiem. Pewność tę dają zachowane po nim dokumenty oraz późniejsza służba w Wojsku Polskim w okresie międzywojennym ${ }^{23}$.

${ }^{22}$ Список подполковникам по стариинству. Составлен по 1-е Января 1898 г., С.-Петербург 1898; Список подполковникам по стариинству. Составлен по 1-е Января 1905 2., С.-Петербург 1905; Список подполковникам по стариинстьу. Составлен по 1-е Мая 1913 г., С.-Петербург 1913; Список полковникам по стариинству. Составлен по 1-е Мал 1901 г.; Список полковникам по старшинству. Составлен по 1-е Марта 1912 г., Список полковникам по стариинству. Составлен по 1-е Марта 1914 г., С.-Петербург 1914.

${ }^{23}$ Centralne Archiwum Wojskowe, Akta personalne Leona Iwanowskiego, sygn. Ap. 624 . 
W posiedzeniach sądów wojskowych brali też udział oficerowie polskiego pochodzenia. Wybierano wówczas oficerów starszych stopniem, którzy mieli duże doświadczenie wojskowe. Wśród czasowych członków sądu okręgowego można odnaleźć np. ppłka Mariana Kaminskiego s. Ludwika ${ }^{24}$. Oficerów polskiego pochodzenia można było często spotkać w składzie sądów pułkowych. Jednym z nich był np. Jan Rządkowski²5.

Skład wyznaniowy opisywanej grupy osób był przeważnie prawosławny. Zdarzali się jednak przedstawiciele innych wyznań, głównie protestanci, np. Marceli Chonskij, Gustaw Adolf Firenkranc czy Leon Iwanowskij. Nie spotykało się wśród nich rzymskich katolików.

Wszyscy oficerowie pracujący w wojskowym wymiarze sprawiedliwości okręgu przeszli standardową drogę oficera służącego w armii - od wojskowej szkoły średniej po akademię. Spośród 85 osób średnie szkoły wojskowe ukończyło co najmniej 35 osób. Szkołami tego typu były gimnazja wojskowe, zreorganizowane później w korpusy kadetów. Nauka w nich trwała około 7 lat i odbywała się na koszt państwa. Absolwenci tych szkół byli później przyjmowani do różnych specjalistycznych szkół wojskowych.

Wojskowe szkoły specjalne kształciły przyszłych oficerów na potrzeby wszystkich rodzajów wojsk - piechoty, kawalerii, artylerii i wojsk inżynieryjnych. Nauka w nich trwała, w zależności od profilu kształcenia, dwa lub trzy lata. Absolwenci tych szkół byli promowani na pierwszy stopień oficerski. Oficerów kształcono także w szkołach junkrów piechoty. Z omawianej grupy ten typ szkół ukończyła zdecydowana większość osób, około 60 .

Zdecydowana większość oficerów ukończyła specjalistyczne szkoły wojskowe - Pawłowska, Konstantynowską (najwięcej absolwentów) i Aleksiejewską. Pojedyncze osoby - szkoły junkrów piechoty, głównie w Moskwie i jedna w Wilnie (Leon Iwanowski).

Wszyscy oficerowie ukończyli Wojskową Akademię Prawną w Petersburgu, która umożliwiała piastowanie stanowisk w opisywanym zarządzie. Studia tutaj trwały dwa lata. Egzaminy wstępne do akademii były dwustopniowe. Pierwszy stopień, w okręgach wojskowych, przeprowadzano $\mathrm{w}$ czerwcu, natomiast drugi w samej akademii $\mathrm{w}$ sierpniu lub wrześniu. Egzaminy każdego szczebla trwały około dwóch tygodni ${ }^{26}$. Obowiązujące przepisy zakładały przyjęcie do akademii maksymalnie 30

${ }^{24}$ APL, RGL (1867-1918), sygn. WP II 1906:78, ПВВВО, 1906, nr 130; Список подполковникам по стариинству. Составлен по 1-е Января 1905 г., s. 1205.

${ }^{25}$ Centralne Archiwum Wojskowe, Akta personalne gen. Jana Rządkowskiego, sygn. Ap. 6018, VM 45/3520, VM 89/8357.

${ }^{26}$ СВП 1869 года, ks. XV, art. 5, 13. 
słuchaczy. Liczba oficerów z każdego okręgu wojskowego była uzależniona od ilości stacjonujących w nim dywizji piechoty. Okręgi Wschodniosyberyjski, Omski, Turkiestański i Kaukaski mogły mieć najwyżej po jednym oficerze na roku ${ }^{27}$.

Do Wojskowej Akademii Prawniczej mieli wstęp wszyscy sztabi oberoficerowie, którzy ukończyli średnie i wyższe szkoły wojskowe lub zdali w nich egzaminy końcowe. Musieli posiadać również co najmniej cztery lata wysługi ${ }^{28}$. Każdemu oficerowi chcącemu wstąpić do akademii wojskowej przysługiwał trzymiesięczny urlop na przygotowanie się do egzaminów. Oficerów posiadających dyplom ukończenia studiów uniwersyteckich zwalniano $z$ egzaminu do akademiii ${ }^{29}$. Egzaminy obejmowały następujące przedmioty: język rosyjski, historię polityczną, geografię, administrację wojskowa ustawę o służbie garnizonowej, język obcy (niemiecki, francuski lub angielski). Ukończenie akademii dawało wyższe wykształcenie wojskowe i prawnicze ${ }^{30}$.

Oficer przechodząc do wojskowego wymiaru sprawiedliwości miał zachowywany, podwyższany lub zmniejszany stopień wojskowy. Przy przejściu z wojsk liniowych stopień wojskowy zmniejszano, z artylerii zachowywano, z gwardii - awansowano na kolejny stopień wojskowy ${ }^{31}$.

W omawianej grupie oficerów kilku wywodziło się z oddziałów gwardii. Większość z nich służyła wcześniej w Izmajłowskim Pułku Gwardii stacjonującym w Sankt Petersburgu, jak: Wasilij Arbuzow, Nikołaj Doroszewskij, Jewgienij Koziełkin, Wasilij Pienkin, Georgij Rudenko, natomiast inni - w Wołyńskim Pułku Gwardii - Konstantin Bołdeskul, 2. Batalionie Strzelców Gwardii - ks. Siergiej Druckoj, Pawłowskim Pułku Gwardii Siergiej Minin, Kozackim Pułku Gwardii - Lew Płanson.

Oficerowie służący w wojskowym wymiarze sprawiedliwości pięli się stosunkowo szybko po szczeblach kariery służbowej. Po ukończeniu akademii byli kandydatami do objęcia stanowiska w wojskowym wymiarze sprawiedliwości, następnie zajmowali funkcje pomocnika prokuratora wojskowego, śledczego wojskowego, sędziego wojskowego, prokuratora wojskowym, prezesa sądu okręgowego, członka głównego sądu wojskowego, głównego prokuratora wojskowego i prezesa głównego sądu wojskowego.

\footnotetext{
${ }^{27}$ APL, RGL (1867-1918), sygn. WP I 1883:7, Приказ по Военному Ведомству, 1883, nr 9.

${ }^{28}$ СВП 1869 года, ks. XV, art. 16.

${ }^{29}$ СВП 1869 года, ks. XV, art. 22.

${ }^{30}$ В. Кузмин-Караваев, Военно-Юридическая Академия 1866-1891 г2. Краткий исторический очерк, С.-Петербург 1891.

${ }^{31}$ СВП 1869 года, ks. XXIV, art. 162.
} 
$\mathrm{W}$ armii rosyjskiej na kolejne stopnie wojskowe awansowano co cztery lata. Pewien problem pojawiał się przy mianowaniu na stopień kapitana i stopnie wyższe (podpułkownik, pułkownik), gdzie wymagane było istnienie wakującego stanowiska służbowego danego szczebla. Szybciej niż przeciętni oficerowie awansowali absolwenci akademii, jednak nie było reguły, o ile lat czas ten ulegał skróceniu. W armii rosyjskiej na stopień podpułkownika awansowano po około 21 latach służby w stopniu oficerskim. Oficerowie wojskowego wymiaru sprawiedliwości ten stopień osiągali po 10-15 latach służby ${ }^{32}$.

Sprawy, które rozpatrywano, dotyczyły przede wszystkim wykroczeń popełnionych przez żołnierzy. Specjalne posiedzenia sądów odbywały się w wyznaczonych miejscach i terminach oraz w ustalonych wcześniej składach. Sprawozdania z działalności tych sądów zamieszczano w specjalnych rozkazach wydawanych do wojsk okręgu. Informowano wówczas o popełnionym przestępstwie i karze za nie. W przypadku oficerów podawano tylko artykuł, na którego podstawie byli karani ${ }^{33}$.

Statystykę działalności wojskowego wydziału sprawiedliwości zamieszczano w specjalnych sprawozdaniach Ministerstwa Wojny za konkretny rok. Wydawnictwo to informowało o działalności poszczególnych zarządów wchodzących w skład resortu wojny i podawało zbiorcze statystyki przestępczości i jej wykrywalności w armii. Informacje dotyczyły liczby spraw wpływających, rozpoczętych, zakończonych itp. Oddzielne informacje odnosiły się do przestępczości wśród oficerów, żołnierzy niższych rangą (podoficerowie i szeregowi) oraz urzędników. Robiono specjalne wyliczenia pokazujące przestępczość w poszczególnych okręgach wojskowych, rodzajach sił zbrojnych, z podziałem na rodzaje przestępstw (np. nadużycie uprawnień służbowych, malwersacje finansowe i gospodarcze, sprzeniewierzenie mienia państwowego, napady, dezercje, naruszenie godności osobistej czy naruszenie moralności). Informowano także o wymiarze kar, jaki zastosowano, aresztu po karę śmierci włącznie, złagodzeniach wyroku itp. ${ }^{34}$

${ }^{32}$ Leon Iwanowski stopień ppłka osiągnął po 15 latach służby. Adam Zaliwski stopień ppłka osiągnął po 13 latach służby, a Konstantin Bołdeskul czy Georgij Lisowskij - po 10 latach służby w stopniu oficerskim.

${ }^{33}$ Zob. APL, RGL (1867-1918), sygn.: WP II 1889:15/2; WP II 1896:58; WP I 1899:10; WP I 1905:67; WP I 1906:78; WP I 1910:57.

${ }^{34}$ Zob. Всеподанейший отчет о действиях Военного Министерства за 1897 год. Представлен Государью Илператору 31-го Декабря 1898 года, С.-Петербург 1899, s. 82-91, załącznik Отчет Главного военно-судного управления за 1897 год; Всеподаннейиий отчет о действиях Военного Министерства за 1910 год, С.-Петербург 1910, s. 58-66, załącznik Отчет Главного военно-судного управления за 1910 год. 
Wojskowy wymiar sprawiedliwości WOW (Zarząd Sądowy Wojskowego Okręgu Wojskowego) był jednym ze sprawniejszych tego typu zarządów w armii rosyjskiej. Skala jego działalności była duża, ponieważ WOW był jednym z najważniejszych i najliczniejszych okręgów w cesarstwie. Kierowano do niego także dobrze przygotowaną merytorycznie kadrę, która w całości była kształcona w akademii wojskowej, co w ówczesnej armii było rzadkością.

Wymiar sprawiedliwości Warszawskiego Okręgu Wojskowego jest tematem bardzo obszernym i do tej pory w Polsce mało znanym. Analiza jego działalności pozwala na uchwycenie pewnej części wewnętrznego życia armii rosyjskiej na przełomie XIX i XX wieku. Szczególnie dotyczy to jego obszarów leżących na granicy prawa, a często z jego przekroczeniem. Rozbudowane statystyki ukazują ich skalę, jednak jednostkowe opisy poszczególnych spraw dają wiele cennych informacji o życiu gospodarczym i społecznym tego hermetycznego świata. Ukazują także często nieznane obrazki z historii ziem polskich okresu zaborów.

Tabela 1. Wykaz szkół wojskowych ukończonych przez oficerów wymiaru sprawiedliwości Warszawskiego Okręgu Wojskowego armii rosyjskiej na przełomie XIX i XX wieku

\begin{tabular}{|l|c|c|c|}
\hline \multicolumn{1}{|c|}{ Nazwisko i imię } & Szkoła średnia & Szkoła wojskowa & Akademia \\
\hline $\begin{array}{l}\text { Abdułow Anatolij } \\
\text { Władimirowicz }\end{array}$ & Brak danych & $\begin{array}{c}\text { 1 Pawłowska Szkoła } \\
\text { Wojskowa (1 PSW) }\end{array}$ & $\begin{array}{c}\text { Akademia Wojenna } \\
\text { Prawna (AWP) }\end{array}$ \\
\hline $\begin{array}{l}\text { Afanasjew Michaił } \\
\text { Jemielianowicz }\end{array}$ & Brak danych & Brak danych & AWP \\
\hline $\begin{array}{l}\text { Andrianow Aleksander } \\
\text { Aleksandrowicz }\end{array}$ & Brak danych & Brak danych & AWP \\
\hline $\begin{array}{l}\text { Andriejew Aleksander } \\
\text { Piotrowicz }\end{array}$ & Brak danych & Brak danych & AWP \\
\hline $\begin{array}{l}\text { Arbuzow Wasilij } \\
\text { Aleksiejewicz }\end{array}$ & Brak danych & $\begin{array}{c}\text { Mikołajewska Szkoła } \\
\text { Kawaleryjska }\end{array}$ & AWP \\
\hline $\begin{array}{l}\text { Bielawskij Aleksander } \\
\text { Nikołajewicz }\end{array}$ & $\begin{array}{c}\text { Gimnazjum } \\
\text { W Warszawie }\end{array}$ & $\begin{array}{c}\text { Moskiewska Szkoła } \\
\text { Wojskowa }\end{array}$ & AWP \\
\hline $\begin{array}{l}\text { Birszert Aleksander } \\
\text { Aleksandrowicz }\end{array}$ & $\begin{array}{c}\text { Wojskowe w Sankt } \\
\text { Petersburgu }\end{array}$ & $\begin{array}{c}\text { Szkoła Wojskowa } \\
\text { (2 KSW) }\end{array}$ & AWP \\
\hline $\begin{array}{l}\text { Bogdanow Paweł } \\
\text { Iwanowicz }\end{array}$ & Brak danych & $\begin{array}{c}\text { Michajłowski Instytut } \\
\text { Mierniczy }\end{array}$ & A \\
\hline
\end{tabular}


ciąg dalszy tab. 1

\begin{tabular}{|c|c|c|c|}
\hline $\begin{array}{l}\text { Bołdeskul Konstantin } \\
\text { Iwanowicz }\end{array}$ & Brak danych & Brak danych & AWP \\
\hline $\begin{array}{l}\text { Borysoglebskij Siergiej } \\
\text { Arkadiewicz }\end{array}$ & $\begin{array}{l}\text { Szkoła Realna } \\
\text { w Astrachaniu }\end{array}$ & $\begin{array}{l}\text { Moskiewska Szkoła } \\
\text { Junkrów Piechoty }\end{array}$ & AWP \\
\hline $\begin{array}{l}\text { Chaskin Andriej } \\
\text { Władimirowicz }\end{array}$ & Brak danych & $1 \mathrm{PSW}$ & AWP \\
\hline $\begin{array}{l}\text { Cholawko Iwan } \\
\text { Michajłowicz }\end{array}$ & Brak danych & Brak danych & AWP \\
\hline $\begin{array}{l}\text { Chonskij Marceli } \\
\text { Stanisławowicz }\end{array}$ & Brak danych & $\begin{array}{l}\text { Mikołajewska Szkoła } \\
\text { Inżynieryjna }\end{array}$ & AWP \\
\hline $\begin{array}{l}\text { Czywadze Konstantin } \\
\text { Aleksandrowicz }\end{array}$ & $\begin{array}{l}\text { Korpus Kadetów } \\
\text { w Tyflisie }\end{array}$ & $\begin{array}{c}3 \text { Aleksiejewska Szkoła } \\
\text { Wojskowa ( } 3 \mathrm{ASW})\end{array}$ & AWP \\
\hline $\begin{array}{l}\text { Ditiatjew Władimir } \\
\text { Dmitrjewicz }\end{array}$ & Brak danych & Brak danych & AWP \\
\hline $\begin{array}{l}\text { Djakow Michaił } \\
\text { Ardalionowicz }\end{array}$ & $\begin{array}{l}\text { Korpus Kadetów } \\
\text { w Pskowie }\end{array}$ & $2 \mathrm{KSW}$ & AWP \\
\hline $\begin{array}{l}\text { Dobrowolskij Aleksan- } \\
\text { der Michajłowicz }\end{array}$ & $\begin{array}{c}\text { Gimnazjum } \\
\text { Wojskowe w Kijowie }\end{array}$ & $2 \mathrm{KSW}$ & AWP \\
\hline $\begin{array}{l}\text { Dobrianskij Aleksander } \\
\text { Michajłowicz }\end{array}$ & $\begin{array}{c}\text { Męskie Gimnazjum } \\
\text { Klasyczne } \\
\text { w Chełmie }\end{array}$ & $\begin{array}{l}\text { Moskiewska Szkoła } \\
\text { Junkrów Piechoty }\end{array}$ & AWP \\
\hline $\begin{array}{l}\text { Dorogoj Paweł } \\
\text { Aleksandrowicz }\end{array}$ & $\begin{array}{l}2 \text { Korpus Kadetów } \\
\text { w Sankt Petersburgu }\end{array}$ & $1 \mathrm{PSW}$ & AWP \\
\hline $\begin{array}{l}\text { Doroszewskij Nikołaj } \\
\text { Fiodorowicz }\end{array}$ & $\begin{array}{l}\text { Gimnazjum Męskie } \\
\text { w Czernihowie }\end{array}$ & $2 \mathrm{KSW}$ & AWP \\
\hline $\begin{array}{l}\text { ks. Druckoj Siergiej } \\
\text { Aleksandrowicz }\end{array}$ & Brak danych & $3 \mathrm{ASW}$ & AWP \\
\hline $\begin{array}{l}\text { Duble Jakow } \\
\text { Jewgienjewicz }\end{array}$ & Brak danych & $3 \mathrm{ASW}$ & AWP \\
\hline $\begin{array}{l}\text { Firenkranc Gustaw } \\
\text { Juliewicz }\end{array}$ & $\begin{array}{l}\text { Piotrowski Korpus } \\
\text { Kadetów w Połtawie }\end{array}$ & $3 \mathrm{ASW}$ & AWP \\
\hline Girs Nikołaj Pawłowicz & Brak danych & $\begin{array}{l}\text { Konstantynowska } \\
\text { Szkoła Artylerii }\end{array}$ & AWP \\
\hline $\begin{array}{l}\text { Gorskij Aleksander } \\
\text { Michajłowicz }\end{array}$ & Brak danych & Brak danych & AWP \\
\hline
\end{tabular}


ciąg dalszy tab. 1

\begin{tabular}{|c|c|c|c|}
\hline $\begin{array}{l}\text { Granowskij Diodor } \\
\text { Piotrowicz }\end{array}$ & $\begin{array}{l}4 \text { Moskiewski } \\
\text { Korpus Kadetów }\end{array}$ & $2 \mathrm{KSW}$ & AWP \\
\hline $\begin{array}{l}\text { Granowski Dymitr } \\
\text { Piotrowicz }\end{array}$ & Brak danych & Brak danych & AWP \\
\hline $\begin{array}{l}\text { Gorodeckij Piotr } \\
\text { Pawłowicz }\end{array}$ & $\begin{array}{l}\text { Korpus Kadetów } \\
\text { w Symbirsku }\end{array}$ & $1 \mathrm{PSW}$ & AWP \\
\hline $\begin{array}{l}\text { Ignatowicz Władimir } \\
\text { Jewgrafowicz }\end{array}$ & $\begin{array}{l}2 \text { Moskiewski } \\
\text { Korpus Kadetów }\end{array}$ & $\begin{array}{c}\text { Michajłowska Szkoła } \\
\text { Artylerii }\end{array}$ & AWP \\
\hline $\begin{array}{l}\text { Iwanowski Leon } \\
\text { Konstanty }\end{array}$ & $\begin{array}{l}8 \text { Gimnazjum Męskie } \\
\text { w Sankt Petersburgu }\end{array}$ & $\begin{array}{l}\text { Wileńska Szkoła } \\
\text { Junkrów Piechoty }\end{array}$ & AWP \\
\hline $\begin{array}{l}\text { Jakubowskij Mitrofan } \\
\text { Iwanowicz }\end{array}$ & Brak danych & Brak danych & AWP \\
\hline $\begin{array}{l}\text { Jawlenskij Siergiej } \\
\text { Georgijewicz }\end{array}$ & $\begin{array}{l}2 \text { Gimnazjum } \\
\text { Wojskowe } \\
\text { w Moskwie }\end{array}$ & $3 \mathrm{ASW}$ & AWP \\
\hline $\begin{array}{l}\text { Jerancow Aleksander } \\
\text { Fiodorowicz }\end{array}$ & Brak danych & Brak danych & AWP \\
\hline $\begin{array}{l}\text { Kamienskij Paweł } \\
\text { Jewgieniewicz }\end{array}$ & Korpus kadetów & $2 \mathrm{KSW}$ & AWP \\
\hline $\begin{array}{l}\text { Kaminskij Anatolij } \\
\text { Francewicz }\end{array}$ & $\begin{array}{l}2 \text { Gimnazjum } \\
\text { Wojskowe } \\
\text { w Moskwie }\end{array}$ & $2 \mathrm{KSW}$ & AWP \\
\hline $\begin{array}{l}\text { Kann Wiaczesław } \\
\text { Wiaczesławowicz }\end{array}$ & Brak danych & Brak danych & AWP \\
\hline $\begin{array}{l}\text { Kaznaczajew Nikołaj } \\
\text { Władimirowicz }\end{array}$ & $\begin{array}{l}2 \text { Gimnazjum } \\
\text { Wojskowe } \\
\text { w Moskwie }\end{array}$ & $2 \mathrm{KSW}$ & AWP \\
\hline $\begin{array}{l}\text { Koziełkin Jewgienij } \\
\text { Nikołajewicz }\end{array}$ & $\begin{array}{c}\text { Gimnazjum } \\
\text { Wojskowe w Orle }\end{array}$ & $2 \mathrm{KSW}$ & AWP \\
\hline $\begin{array}{l}\text { Krechowiecki-Juszczen- } \\
\text { ko Siergiej Fiodorowicz }\end{array}$ & $\begin{array}{l}\text { Gimnazjum Wojsko- } \\
\text { we w Niżnym } \\
\text { Nowogrodzie }\end{array}$ & $1 \mathrm{PSW}$ & AWP \\
\hline $\begin{array}{l}\text { Kretcer Aleksander } \\
\text { Robertowicz }\end{array}$ & Brak danych & Brak danych & AWP \\
\hline $\begin{array}{l}\text { Kuleszow Iwan } \\
\text { Piotrowicz }\end{array}$ & Szkoła realna & $\begin{array}{l}\text { Moskiewska Szkoła } \\
\text { Wojskowa }\end{array}$ & AWP \\
\hline
\end{tabular}


ciąg dalszy tab. 1

\begin{tabular}{|c|c|c|c|}
\hline $\begin{array}{l}\text { Lipkin Maksim } \\
\text { Ksenofontowicz }\end{array}$ & $\begin{array}{l}\text { Gimnazjum Wojsko- } \\
\text { we w Połocku }\end{array}$ & $2 \mathrm{KSW}$ & AWP \\
\hline $\begin{array}{l}\text { Lisowskij Georgij } \\
\text { Ipolitowicz }\end{array}$ & $\begin{array}{l}\text { Nikołajewski } \\
\text { Korpus Kadetów }\end{array}$ & $\begin{array}{c}\text { Mikołajewska Szkoła } \\
\text { Kawaleryjska }\end{array}$ & AWP \\
\hline $\begin{array}{l}\text { Ładyżenskij Władimir } \\
\text { Ilicz }\end{array}$ & Brak danych & Brak danych & AWP \\
\hline $\begin{array}{l}\text { Łazariew Władimir } \\
\text { Iwanowicz }\end{array}$ & Brak danych & $\begin{array}{l}\text { Kijowska Szkoła } \\
\text { Wojskowa }\end{array}$ & $\begin{array}{c}\text { Cesarski Uniwer- } \\
\text { sytet Moskiewski, } \\
\text { AWP }\end{array}$ \\
\hline $\begin{array}{l}\text { Maszrub-Szowerdow } \\
\text { Siergiej Iwanowicz }\end{array}$ & Brak danych & Brak danych & AWP \\
\hline $\begin{array}{l}\text { Miłkow Aleksander } \\
\text { Pawłowicz }\end{array}$ & $\begin{array}{l}\text { Seminarium } \\
\text { duchowne }\end{array}$ & $3 \mathrm{ASW}$ & $\begin{array}{c}\text { Michajłowska } \\
\text { Akademia Artylerii, } \\
\text { AWP }\end{array}$ \\
\hline $\begin{array}{l}\text { Minin Siergiej } \\
\text { Piotrowicz }\end{array}$ & $\begin{array}{l}2 \text { Gimnazjum } \\
\text { Wojskowe } \\
\text { w Moskwie }\end{array}$ & $3 \mathrm{ASW}$ & AWP \\
\hline $\begin{array}{l}\text { Mower Wasilij } \\
\text { Aleksiejewicz }\end{array}$ & Brak danych & Brak danych & AWP \\
\hline Muchin Piotr Piotrowicz & $\begin{array}{c}\text { Gimnazjum } \\
\text { Wojskowe w Kijowie }\end{array}$ & $\begin{array}{c}2 \text { KSW, Michajłowska } \\
\text { Szkoła Artylerii }\end{array}$ & AWP \\
\hline $\begin{array}{l}\text { Musznikow Aleksander } \\
\text { Aleksandrowicz }\end{array}$ & $\begin{array}{l}2 \text { Gimnazjum } \\
\text { Wojskowe w Sankt } \\
\text { Petersburgu }\end{array}$ & $1 \mathrm{PSW}$ & AWP \\
\hline $\begin{array}{l}\text { Nikitin Władimir } \\
\text { Władimirowicz }\end{array}$ & Brak danych & Brak danych & AWP \\
\hline $\begin{array}{l}\text { Niszczenkow Władimir } \\
\text { Nikanorowicz }\end{array}$ & $\begin{array}{l}1 \text { Gimnazjum } \\
\text { Wojskowe w Sankt } \\
\text { Petersburgu }\end{array}$ & $2 \mathrm{KSW}$ & AWP \\
\hline $\begin{array}{l}\text { Panow Iwan } \\
\text { Ardalionowicz }\end{array}$ & $\begin{array}{l}\text { Korpus Kadetów } \\
\text { w Pskowie }\end{array}$ & $1 \mathrm{PSW}$ & AWP \\
\hline $\begin{array}{l}\text { Peretc Grigorij } \\
\text { Grigorjewicz }\end{array}$ & Brak danych & Brak danych & AWP \\
\hline $\begin{array}{l}\text { Perzeke Friedrich } \\
\text { Adolfowicz }\end{array}$ & $\begin{array}{l}\text { Gimnazjum Męskie } \\
\text { w Lipawie }\end{array}$ & $2 \mathrm{KSW}$ & AWP \\
\hline $\begin{array}{l}\text { Pienkin Wasilij } \\
\text { Konstantinowicz }\end{array}$ & $\begin{array}{l}2 \text { Gimnazjum } \\
\text { Wojskowe } \\
\text { w Moskwie }\end{array}$ & $3 \mathrm{ASW}$ & AWP \\
\hline
\end{tabular}


ciąg dalszy tab. 1

\begin{tabular}{|c|c|c|c|}
\hline $\begin{array}{l}\text { Płanson Lew } \\
\text { Antonowicz }\end{array}$ & $\begin{array}{c}3 \text { Gimnazjum woj- } \\
\text { skowe w Sankt } \\
\text { Petersburgu }\end{array}$ & $\begin{array}{c}\text { Mikołajewska Szkoła } \\
\text { Kawalerii }\end{array}$ & AWP \\
\hline $\begin{array}{l}\text { Płanson Iwan } \\
\text { Ardalionowicz }\end{array}$ & Brak danych & Brak danych & AWP \\
\hline $\begin{array}{l}\text { Polakow Siergiej } \\
\text { Aleksandrowicz }\end{array}$ & Brak danych & Brak danych & AWP \\
\hline $\begin{array}{l}\text { Potapow Nikołaj } \\
\text { Aleksandrowicz }\end{array}$ & $\begin{array}{c}\text { Szkoła Realna } \\
\text { w Sankt Petersburgu }\end{array}$ & $\begin{array}{c}\text { Mikołajewska Szkoła } \\
\text { Kawalerii }\end{array}$ & AWP \\
\hline $\begin{array}{l}\text { Riezanow Aleksander } \\
\text { Siemionowicz }\end{array}$ & $\begin{array}{l}\text { Syberyjski Korpus } \\
\text { Kadetów }\end{array}$ & $1 \mathrm{PSW}$ & AWP \\
\hline $\begin{array}{l}\text { Rossowskij Władimir } \\
\text { Andriejewicz }\end{array}$ & Brak danych & $2 \mathrm{KSW}$ & AWP \\
\hline $\begin{array}{l}\text { Rudenko Georgij } \\
\text { Iwanowicz }\end{array}$ & $\begin{array}{l}\text { Gimnazjum Wojsko- } \\
\text { we w Połtawie }\end{array}$ & $2 \mathrm{KSW}$ & AWP \\
\hline $\begin{array}{l}\text { Sawiełow Nikołaj } \\
\text { Nikołaj }\end{array}$ & Korpus kadetów & $\begin{array}{c}\text { Konstantynowska Szkoła } \\
\text { Artylerii }\end{array}$ & AWP \\
\hline $\begin{array}{l}\text { Sielieckij Aleksander } \\
\text { Fiodorowicz }\end{array}$ & Brak danych & $\begin{array}{l}1 \text { PSW, Michajłowska } \\
\text { Szkoła Artylerii }\end{array}$ & $\begin{array}{c}\text { Mikołajewska } \\
\text { Akademia Sztabu } \\
\text { Generalnego, AWP }\end{array}$ \\
\hline $\begin{array}{l}\text { Semplikiewicz } \\
\text { Aleksander } \\
\text { Timofiejewicz }\end{array}$ & $\begin{array}{l}\text { Piotrowski Korpus } \\
\text { Kadetów w Połtawie }\end{array}$ & $2 \mathrm{KSW}$ & AWP \\
\hline $\begin{array}{l}\text { Siemienow Lew } \\
\text { Piotrowicz }\end{array}$ & $\begin{array}{l}\text { Korpus Kadetów } \\
\text { w Symbirsku }\end{array}$ & $\begin{array}{c}\text { Konstantynowska Szkoła } \\
\text { Artylerii }\end{array}$ & AWP \\
\hline $\begin{array}{l}\text { Smirnow Anatolij } \\
\text { Iwanowicz }\end{array}$ & $\begin{array}{l}\text { Gimnazjum Męskie } \\
\text { w Wołogdzie }\end{array}$ & $\begin{array}{l}\text { Moskiewska Szkoła } \\
\text { Junkrów Piechoty }\end{array}$ & AWP \\
\hline $\begin{array}{l}\text { Stanisławskij Aleksiej } \\
\text { Wasijewicz }\end{array}$ & Brak danych & $\begin{array}{l}\text { Mikołajewska Szkoła } \\
\text { Inżynierii }\end{array}$ & AWP \\
\hline $\begin{array}{l}\text { Strielnikow Fiodor } \\
\text { Jefimowicz }\end{array}$ & Brak danych & Brak danych & $\begin{array}{c}\text { Mikołajewska } \\
\text { Akademia Sztabu } \\
\text { Generalnego, AWP }\end{array}$ \\
\hline $\begin{array}{l}\text { Szapko Walerian } \\
\text { Wasiljewicz }\end{array}$ & $\begin{array}{l}\text { Gimnazjum Męskie } \\
\text { w Żytomierzu }\end{array}$ & $2 \mathrm{KSW}$ & AWP \\
\hline $\begin{array}{l}\text { Szawrow Borys } \\
\text { Władimirowicz }\end{array}$ & $\begin{array}{l}\text { Korpus Kadetów } \\
\text { w Orenburgu }\end{array}$ & $3 \mathrm{ASW}$ & AWP \\
\hline
\end{tabular}


ciąg dalszy tab. 1

\begin{tabular}{|c|c|c|c|}
\hline $\begin{array}{l}\text { Szebeko Lew } \\
\text { Iwanowicz }\end{array}$ & $\begin{array}{l}3 \text { Gimnazjum Woj- } \\
\text { skowe w Moskwie }\end{array}$ & $2 \mathrm{KSW}$ & AWP \\
\hline $\begin{array}{l}\text { Szrejterfeld Konstantin } \\
\text { Nikołajewicz }\end{array}$ & $\begin{array}{l}\text { Korpus Kadetów } \\
\text { w Symbirsku }\end{array}$ & $1 \mathrm{PSW}$ & AWP \\
\hline $\begin{array}{l}\text { Szwejkowskij Piotr } \\
\text { Aleksandrowicz }\end{array}$ & Gimnazjum & $2 \mathrm{KSW}$ & AWP \\
\hline $\begin{array}{l}\text { Tarasienkow Nikołaj } \\
\text { Fiodorowicz }\end{array}$ & $\begin{array}{l}4 \text { Korpus Kadetów } \\
\text { w Moskwie }\end{array}$ & $3 \mathrm{ASW}$ & AWP \\
\hline $\begin{array}{l}\text { Tomilin Jewgienij } \\
\text { Konstantinowicz }\end{array}$ & $\begin{array}{l}\text { Korpus Kadetów } \\
\text { w Kijowie }\end{array}$ & $2 \mathrm{KSW}$ & AWP \\
\hline $\begin{array}{l}\text { Uwerskij Wasilij } \\
\text { Nikołajewicz }\end{array}$ & $\begin{array}{c}\text { Gimnazjum } \\
\text { Wojskowe w Połocku }\end{array}$ & $1 \mathrm{PSW}$ & AWP \\
\hline $\begin{array}{l}\text { Wołodkowskij Aleksiej } \\
\text { Aleksandrowicz }\end{array}$ & Brak danych & Brak danych & AWP \\
\hline $\begin{array}{l}\text { Wysotskij Wiktor } \\
\text { Wiktorowicz }\end{array}$ & Brak danych & Brak danych & AWP \\
\hline $\begin{array}{l}\text { Zabiełło Nikołaj } \\
\text { Nikołajewicz }\end{array}$ & $\begin{array}{l}1 \text { Korpus Kadetów } \\
\text { w Moskwie }\end{array}$ & $3 \mathrm{ASW}$ & AWP \\
\hline $\begin{array}{l}\text { Zagoskin Michaił } \\
\text { Nikołaj }\end{array}$ & Brak danych & $3 \mathrm{ASW}$ & AWP \\
\hline $\begin{array}{l}\text { Zaliwskij Adam } \\
\text { Aleksandrowicz }\end{array}$ & $\begin{array}{l}2 \text { Gimnazjum } \\
\text { Wojskowe } \\
\text { w Moskwie }\end{array}$ & $3 \mathrm{ASW}$ & AWP \\
\hline $\begin{array}{l}\text { Zielenskij Aleksander } \\
\text { Nikołajewicz }\end{array}$ & Brak danych & $\begin{array}{l}\text { Moskiewska Szkoła } \\
\text { Junkrów Piechoty } \\
\text { (roczny kurs) }\end{array}$ & $\begin{array}{c}\text { Cesarski Uniwer- } \\
\text { sytet Moskiewski, } \\
\text { AWP }\end{array}$ \\
\hline
\end{tabular}

Źródło: Список генералам по старшинству. Составлен по 1-е Января 1898 г.; Список генералал по старшинству. Составлен по 1-е Июля 1900 г.; Список генералал по стариинству. Составлен по 1-е Сентября 1905 г.; Список генералах по стариинству. Составлен по 1-е Января 1910 г.; Список генералам по старшинству. Составлен по 15-е Апреля 1914 г.; Список подполковникам по старшинству. Составлен по 1-е Января 1898 г.; Список подполковникам по старшинству. Составлен по 1-е Января 1905 г.; Список подполковникам по старшинству. Составлен по 1-е Мая 1913 г.; Список полковникал по старшинству. Составлен по 1-е Мая 1901 г.; Список полковникам по стариинству. Составлен по 1-е Января 1902 г.; Список полковникам по старшинству. Составлен по 1-е Марта 1912 г.; Список полковниках по старшинству. Составлен по 1-е Марта 19142. 
BIBLIOGRAFIA:

Die Russische Armee, Wien 1901.

Kulik M., Warszawski Okręg Wojskowy Rosyjskiej Cesarskiej Armii (1894-1914), „Przegląd Historyczno-Wojskowy" 2008, nr 4, s. 5-24.

Безугольный А., Ковалевский Н., Ковалев В., История военно-окружной системы в России 1862-1918, Москва 2012.

Военная Энициклопедия, red. К. Величко, t. 5, С.-Петербург 1911.

Волков С. В., Генералитет Российской Илперии. Энциклопедический словарь генералов и адмиралов от Петра I до Николая II, t. I-II, Moskwa 2010.

Кузмин-Караваев В., Военно-Юридическая Академия 1866-1891 г2. Краткий исторический очерк, С.-Петербург 1891.

\section{ABSTRACT:}

During the analysed period the Warsaw Military District encompassed most areas of the Kingdom of Poland and some poviats of the guberniyas of Grodno and Volhynia. The organisational structure of the district was complex, analogically to the structure of the Russian Ministry of War. It was headed by the general-governor, who was at the same time the commander of the district army. He was in charge of regular and irregular units and all military institutions located in this area, including the judicial department, district courts and regiment courts. These employed officers with adequate level of legal education and professional practice. The regulations of that time laid out the scope and mode of investigation of cases. The employment of the judicial department of the Warsaw Military District amounted to around 90 people, however, it was gradually increased. The staff comprised the chair of the court, eight judges, three (later five) investigating officers, ten prosecutors and auxiliary staff. The employees were mainly Russian, though there were also some representatives of other nationalities, including Poles (Leon Iwanowski).

Key words: Russia, the army, Warsaw, military district, judiciary

\section{NOTA O AUTORZE:}

Mariusz Kulik - dr, pracownik Instytutu Historii PAN. W swych badaniach skupia się na dziejach XIX i początków XX wieku, głównie obecności Polaków w Rosji (służba w armii) oraz Rosjan w Królestwie Polskim. Autor opracowania Polacy wśród wyższych oficerów armii rosyjskiej Warszawskiego Okręu Wojskowego (1865-1914). 